\title{
The value of legislative versus electoral experience and gender in explaining candidate list placement in closed list PR
}

\author{
Mihail Chirui, \\ Marina Popescuii
}

Problems of Post-Communism

\begin{abstract}
Candidates' political qualities and personal characteristics reflect what priorities political parties have when they nominate for viable seats. The limited research on the link between candidate characteristics and ranking on closed lists is an important hiatus in understanding legislative recruitment since in closed list PR nomination to top positions on viable lists virtually guarantees election. We address the issue by analyzing longitudinally the determinants of candidate list placement in Romania, an intriguing case given its low proportion of reelected incumbents and women MPs. Our findings indicate that while male candidates are placed higher up on the lists than women, the positive effect of incumbency is larger for female than male incumbents.
\end{abstract}

Keywords: elections, gender, closed list PR, legislative recruitment

\section{Introduction}

In closed list Proportional Representation (PR) systems nomination to top positions of a viable party list virtually guarantees election to parliament even before the first voters enter the polling stations. These nomination decisions of party gatekeepers make a statement about what kind of political qualities, personal experiences and characteristics are salient to the party. The proportion in which members of different groups find themselves in electorally promising list positions is crucial for the quality of substantive and descriptive political representation (Mansbridge 2003) as well as for the likelihood of parliamentary professionalization (Semenova et al 2013). Yet, the 
determinants of candidate list placements have been unfortunately largely ignored by legislative and electoral studies scholars.

Our main argument is that legislative and electoral experienceis valued by party selectorates in their allocation of viable list positions in closed list PR systems, although generally less than in majoritarian systems. Moreover, we expect that in contexts dominated by traditional gender norms women candidates to be discriminated against. The findings of our longitudinal analysis of parliamentary elections in Romania support these expectations and suggest that the few women with legislative experience are rewarded significantly more for it than their male colleagues.

The legislative recruitment literature on closed list PR systems has dealt almost exclusively with the correlates of stronger women representation in parliament (Schmidt 2009) and the likely centralization of the selectorate that this electoral system seems to encourage (Czudnowski, 1975:221; Epstein, 1980; Lundell, 2004: 40; Matthews, 1985: 35-7; Navarro 2012; Kelbel 2014). Thus, with very few exceptions (Gherghina and Chiru 2010; Moraski 2015) scholars have not analyzed the impact of candidate qualifications on the rank positions of the various candidatures on the list. Even when this was done, the analysis only looked at one point in time and targeted either the peculiar case of European Parliament elections (Gherghina and Chiru 2010; Kovár and Kovár 2013) or examined elections in an authoritarian regime (Moraski 2015).

The present article addresses this gap by investigating the determinants of candidate list placement in all Romanian parliamentary elections from 1996 to 2004, i.e. from the first election after the transition to democracy to the last before the 2008 electoral reform that introduced a vote in single member districts instead of closed list PR (Coman 2012; Gherghina and Chiru 2014). This allows us to consider multiple types of candidate qualifications over time in Romania, which is a particularly relevant case for research on candidate list placement in closed list PR for a number of reasons related to both the patterns of recruitment and their outcomes.

First, despite the fact that a closed list PR system was used in all legislative elections from 1990 to 2004, ,ii Romanian parliamentary parties did not ensure the re-election of most of their incumbents even within the limits allowed by the admittedly high electoral volatility. Thus, following the 1992 to 2012 elections the Romanian legislature had in each of its 6 terms a turnover rate larger than 55\% (see Figure 1 and further analysis in Chiru 2010; King and Marian 2015).This outcome is somewhat disconcerting since high rates of incumbency re-election are considered a prerequisite of parliamentary professionalization (Putnam, 1976; Best and Cotta, 2000; Crowther and Matonyte 2007; Semenova et al 2013). Because of this, high incumbency re-election rates should represent an attractive and relatively easy to reach target for party leaders, who may also need to reward incumbents for their service to the party and yield to their informal influence in nomination decisions. Our theory section elaborates on the reasons for which incumbency effects on candidates' electoral prospects might be weaker in PR systems in general and Romania in particular, and our empirical analysis tests these narratives. 
Figure 1 around here ${ }^{i v}$

Second, the proportion of women MPs remained extremely low - albeit slowly risingthroughout the period, at an average of $7.1 \%$ (see Figure 1 above). The Romanian figure is roughly as low as neighboring Hungary had under an electoral system that strongly relied on single-member districts, and is considerably lower than other PR electoral systems produced in the post-communist world (Matland 2003). Given the widely held view that closed list PR is advantageous for women representation (Matland 1998; Ballington 2005; Jones and Navia 1999; Paxton et al. 2010) there may thus be a particularly strong gender bias among Romanian candidate selectors. Our empirical analysis examines one important way through which such a bias could express itself in the data as well as a key mechanism that should work against gender bias in any system where the candidates' legislative experience matters in candidate selection.

Third, legislative recruitment in Romania under closed list PR was generally centralized (Stefan 2004), which should result in particularly clear patterns of nomination and list placement compared to countries where multiple party bodies or groups are involved in the process. Thus, our findings about Romania may shed light on how closed list PR in general may influence patterns of legislative recruitment.

Taking all these elements into account we try to understand how electoral experience, legislative experience and candidates' gender influence the access to viable list positions under closed list PR.

The next section outlines the theoretical framework and hypotheses of our study. The section on research design also discusses data collection efforts and the operationalization of variables, plus descriptive statistics. The analysis section presents the results of our multivariate tests, while the conclusion synthesizes the results and points to further directions of research.

\section{Theoretical framework}

Incumbency advantage seems widespread in legislative elections and is easily explained by a greater experience and within-party influence of incumbents than novices (Cox and Katz 1996; Gelman and Huang 2008). However, incumbency advantage is likely to vary greatly with the type of electoral system used. In a study that analyzed 116 elections from 25 advanced democracies Matland and Studlar (2004) showed that legislative turnover is significantly higher in proportional representation electoral systems than in majoritarian systems. In these elections the average incumbency return rate was close to $68 \%$, which is much higher than in Romania. Similarly, Manow (2007) analyzed 16 federal elections that took place in Germany under the mixed-member proportional system and concluded that SMD MPs have higher chances to be re-elected than list MPs.

Even so, the favorable re-nomination of incumbents should also be a major pattern in most PR systems. Thus, by nominating incumbents on viable places on their lists, parties may send voters a message that they value experience and professionalization in parliamentary politics (Gherghina 2014). Moreover, by placing on top list positions 
incumbents who have developed a reputation for constituency service or have visibility in certain geographical areas (Moraski 2015), the parties may increase the appeal of their lists. As Figure 1 above suggests, there are 2.5 to 3 times more members of an outgoing parliament among MPs elected to a new parliament in Romania than among candidates running in the election. This implies that there may indeed be a positive effect of incumbency on the electoral prospects of Romanian candidates. ${ }^{v}$

However, we argue that the career preferences of MPs and the Romanian parties' electoral calculations, elite recruitment decisions and organizational ethos often work against the re-election of incumbents, producing very high rates of legislative turnovervi (Chiru 2010).

First, at each parliamentary election that took place between 1992 and 2012 at least one third of the MPs, but frequently more, did not run for re-election. Many Romanian MPs prefer continuing their career in local or county politics particularly as mayors or presidents of county councils, as opposed to seeking parliamentary re-election (Chiru et al 2013; Stefan and Grecu, 2013). Second, some newcomers in Romania are preferred for nomination at the expense of incumbents because of their superior resources in terms of personal popularity and name recognition in the district, technocratic expertise, their capacity to finance the election campaign or good relations with party leaders (Stefan 2004; Chiru 2011). For example in 2004 roughly $10 \%$ of the incumbents running for re-election were nominated on completely non-viable lists (i.e. lists that failed to elect any candidate). Third, average electoral volatility was for the entire period higher than $20 \%$ for all parties with the exception of the UDMR and partially of the PSD (Gherghina 2012: 83), and this affects directly the re-election chances of incumbents. Fourth, Romanian parties tend to use the Parliament as a shelter for local and national elites who have lost their executive offices (Stefan and Grecu 2013: 212), a strategy which affects incumbent MPs' re-election chances especially for parties that move from government to opposition. Last but not least, Romanian parties are often seen to be lacking a strong policy-orientation and be built merely as electoral machines that provide access to office for private gain (Frye 2002; Gallagher 2009: 7). These five aspects represent the main reasons behind the possible concrete mechanisms that may suggest these parties value the candidates' electoral potential and experience more than their expertise including in terms of legislative experience.

Thus, if the above characterization of the Romanian parties as electorally driven and only marginally interested in programmatic commitments and policy-making is correct, it is the perceived qualifications of the candidate for vote-seeking rather than for substantive work in designing legislation and policies that parties rewarded more. Since party leaders are themselves parliamentarians and there is a core parliamentary party, incumbents would still have more of a chance to get a list place position conducive to a seat than newcomers but, probably, legislative expertise and professionalization are not the crucial factor. We thus propose as our first hypothesis:

Hypothesis 1: On average candidates with parliamentary experience - i.e., previous incumbency or the total length of legislative service- are more likely to get a promising 
list place but electoral experience (i.e., recent candidacy or the number of previous candidacies in national elections) is likely to matter even more.

More generally, it could be argued that incumbency most probably plays a lesser role under closed list PR than in single member district systems, where its mighty importance was so often confirmed. First, a candidate elected under closed list PR may cultivate a regionally concentrated personal vote and invest in casework on the local scene. But s/he is not authorized to speak on behalf of all local constituents, and is thus less readily recognizable as their voice by citizens who did not vote or voted for a different party than is a candidate elected in a single-member district. This should result in weaker incentives and ability to develop a localized personal following and a weaker and geographically more dispersed personal vote of incumbent candidates, which can influence their electoral fortunes both through the popular vote and the nominating party organs decisions about list placements. Second, under closed list PR, nomination decisions may also be more centralized and thus less easily influenced by ordinary MPs than in single-member district systems, where incumbency often bestows upon them a pre-eminent role in the local party organization too. Third, while in a single member district system the de-selection of an incumbent must be much riskier- it can even signal to the electorate some hitherto unknown wrongdoing of the candidate - under closed list PR displacing an incumbent may well go largely unnoticed. Overall, therefore, we expect that:

Hypothesis 2: Parliamentary experience, i.e. previous incumbency or the total length of legislative service - will have a relatively modest but positive effect on whether candidates are nominated on electorally more promising positions on party lists under closed list PR.

Traditional cultural gender norms conceivably act both against women's nomination on eligible list positions and against voters' positive assessment of their quality and political competence (Paxton et al. 2010; Ruedin 2012). As Valdini (2012: 741) puts it: 'the content of the shortcut of "woman" in a culture with prevalent traditional gender norms is likely to carry negative connotations for that candidate's leadership ability'. After the fall of state socialism Romania witnessed a revival of traditional gender norms (Miroiu and Popescu 2004) in public discourse as well as among the general public and the political elites (Oprica 2008: 34-35; Baluta 2006).

The parliamentary under-representation of women in post-1989 Romania has been well documented (Chiva 2005). Half or more of the districts did not have any female representative in the Chamber of Deputies in a typical legislative term from 1992 until 2008 , and $21 \%$ of all districts failed to elect a single woman MP throughout the entire 1992-2004 period (Dubrow 2006: 98). Moreover, the under-representation of women in the Romanian Parliament is particularly striking, even compared with other postcommunist legislatures ${ }^{\text {vii }}$ such as those in Poland or the Czech Republic (Kunovich 2003; Dubrow 2011). 
A factor that probably contributed to the likely discrimination of women candidates is the absence of women from party elites. A substantial number of women among the party elite increases the perception of qualified women politicians (Sanbonmatsu 2002; Kunovich and Paxton 2005), and the pool from which female candidates for public positions can be drawn. In Romania, high-level party politics was throughout the entire era of closed-list PR an almost exclusively all-male business. Female politicians rarely gained high party leadership positions (Chiva 2005: 982), and none became party leader in the period that we examine here (Chiru and Gherghina 2014: 151). We thus expect that even after controlling for parliamentary experience, ceteris paribus:

Hypothesis 3: Women candidates will be placed lower down on the list compared to men.

That there are indeed severe within-party obstacles to increasing the percentage of female candidates is also confirmed by the largely failed attempts at implementing voluntary gender quotas in three left-wing parties. According to the Quota Project the Democratic Party (PD), the Social Democratic Party (PSD, formerly PDSR) and the Romanian Social Democratic Party (PDSR, absorbed by PSD in 2001) all adopted voluntary gender quotas. Indeed, analyzing the PD party statutes we found that the party had introduced in 1994 a minimum 25\% recommended quota for women 'participation in all the domains of party activity' (art. 16) and the women organization of the party, OFD, received the right to propose at least $25 \%$ women on any list of candidates for appointed or elected office at state or party level (art. 60). These quotas were maintained by the 1998 statute (art. 16 and 53) and increased to a minimum 30\% by the 2001 (art. 15 and 52)and 2003 (art. 15 and 56) party statutes. The 2005 and 2007 statutes maintained the two provisions whereas the 2011 statute only refers to a $30 \%$ recommended quota for women 'participation in all the domains of party activity' (art. 13), without mentioning anymore the quota for party lists. Despite these provisions the share of female candidates the party nominated in parliamentary elections increased only modestly, from $8 \%$ (1992), to $12 \%$ (1996), 16\% (2000) and $21 \%$ (2004) and then fell once again after the 2008 electoral reform introduced an unusual version of PR based on single-member districts: to $10 \%$ in 2008 and $13.3 \%$ in 2012.

The first four PDSR/PSD statutes $(1993,1996,1999,2001)$ do not mention any gender quota. The 2005 statute introduced a minimum $25 \%$ gender quota in the party leadership organs (art. 14). This was maintained by the 2006 statute (art. 14) and increased to $30 \%$ in 2010 (art. 43). Despite the absence from the statutes of specific gender quotas for the party's candidate lists, it seems that the PSD adopted a 30 percent gender quota prior to the 2004 election (Quota Project). Other scholars also maintain that the central PSD leadership had constantly made recommendations to party branches that the share of female candidates in local, parliamentary and European elections should represent 25\% to 30\% (Mihai 2011: 51). Yet at the parliamentary elections the PSD nominated $7 \%$ female candidates in $1992,10 \%$ in $1996,11 \%$ in $2000,23 \%$ in $2004,13 \%$ in 2008 and $11 \%$ in 2012. 
According to the Quota Project the smaller PSDR had a 25 percent quota for women on party lists. It was not possible to verify whether such a provision was indeed included in the party's statutes but the female candidates nominated by this party in parliamentary elections represented $7 \%$ in $1992,17 \%$ in 1996 , and $8 \%$ in 2000 .

The conspicuous failure of the voluntary quotas to reach the target percentages even among the candidates suggests that the gender bias of the largely male selectorate may be particularly strong in Romanian parties. If so, this may add to the explanation of why the percentage of female deputies remained so low in Romania in spite of closed list PR. Such a strong bias may also reveal itself in a weaker capacity of women to maintain their eligible positions on party lists since they do not have sufficient weight in the party especially if their major strength is their legislative experience and expertise, which the parties do not seem to value too much. Moreover, taking into account the traditional gender roles supported by the electorate, party selectorates may also perceive that any women, even those with parliamentary experience, may have a lower electoral appeal than men with a similar profile. This suggests:

Hypothesis 4: The positive effect of incumbency on obtaining electorally viable list placements is weaker for women than male candidates.

Note that all our hypotheses, if supported, paint a bleak picture about the prospects of legislative professionalization and gender equality in Romania. Conversely, their rejection would imply that while Romanian political parties may not build particularly strong programmatic linkages with their electorates, they (1) do nonetheless appreciate legislative experience among their candidates, maybe even at the expense of electoral experience or against popular prejudices about female candidates; and (2) in spite of the strong gender imparity in the composition of the party bodies deciding about list placements, Romanian party selectorates are not biased against female candidates, and thus women's underrepresentation in parliament must find it its explanation in the broader social and political process.

\section{Research design}

Data source and selection of observations

The data used is based on official election results matched with data from 'The Romanian Parliamentary Candidates Study 1990-2012' (Chiru and Popescu 2014). For the 1992-2000 elections the names of the candidates, their party affiliation, list position and the county where they ran were retrieved from the official gazette Monitorul Oficial, which publishes all official public documents including new legislation passed by the Parliament. The election reports published by Monitorul Oficial included the list of elected candidates as well as the list of substitutes, meaning all unelected candidates on a county party list who would replace an MP in case of resignation or death. Unfortunately, the list of substitutes was reported only for those counties where the party won at least a seat. viii For the 2004, 2008 and 2012 elections the Romanian Parliamentary Candidates Study contains data on all the candidates (from 
parliamentary, non-parliamentary parties and independents)obtained from the Romanian Permanent Electoral Authority.

We manually coded candidates' gender and incumbency status. For the latter, we considered a candidate to be incumbent if s/he acted as an MP during the last legislative term, irrespective of the duration of mandate, thus including those candidates who were substitute MPs or resigned. By matching records across years we could determine who ran in how many elections, and how many years they spent in Parliament.

We focused only on the candidates and elections for which our research questions about the relative impact of electoral and legislative experience were relevant. Thus the data on the 2008 and 2012 elections were not used because the 2008 reform replaced the closed list PR system with an original mixed member proportional formula in which all candidates are elected in SMDs. We had to leave out the 1990 election because the candidates had no relevant variance regarding legislative and electoral experience. The 1990 data was also plagued by a severe data availability problem in that the election report published by Monitorul Oficial included only the list of elected candidates.Therefore we could not create some of the relevant independent variables required for the analysis of the 1992 election and consequently our models were only estimated to explain list placements in 1996, 2000 and 2004. We pool data from lower and upper house elections because both chambers had virtually the same electoral system and exactly symmetrical powers throughout the 1992-2004 period. ${ }^{\text {ix }}$ Candidates competing for the reserved ethnic minority seats were excluded from the analysis as these candidates compete under distinct electoral rules in non-territorially organized single-member seat contests. They are also not part of the same type of electoral competition with few minorities having competing organizations on the ballot. Their goal is generally to reach the required number of votes to be allocated the seat reserved for each specific recognized minority.

The fact that our data for the 1992, 1996 and 2000 elections is systematically biased by the absence of candidates from counties where the given party did not win any mandate does not raise major concerns given that our interest is in the factors that help nomination for eligible positions. This is what matters most for understanding what are the party selectorates' priorities in terms of representation and also how the Parliament would eventually look like. Consider the UDMR, the party of the Hungarian minority that is underrepresented in our data because of the sample bias in question. The party only won seats attached to counties outside of its ethnic stronghold extremely rarely, as a result of the unforeseeable play of mandate redistributions at the second, national tier of allocation. Hence nomination to lead a list in a county where the party did not win seats carried hardly any more significance than nomination for any other place on the same list, or for not being nominated at all. We can, however, run our models for the 2004 election both on the full population of candidates and on the sample of party lists that won at least a mandate. As we shall see in the tables below, there is no substantive difference between the results on the broader and the more restricted sample of the 2004 candidates. 


\section{Models and variables}

The dependent variable in our analysis (Relative List Placement) is meant to capture how close a certain list position is to being an actually winnable or a safe seat in the given election. We proxy the parties' regionally differentiated expectations by assuming that, except for an unknown amount of errors randomly distributed across counties, they had perfectly informed expectations about where they can expect to win more and less seats, and constructed their lists accordingly. Therefore, Relative List Placement, the dependent variable throughout our analysis, was constructed by subtracting all candidates' actual list placement - from 1 for the top candidate to some 30 for the lowest placed candidates -from the number of seats won by their own party (Party Magnitude) in the constituency where they were running as a candidate. Thus, Relative List Placement assumes non-negative values for all candidate who were actually elected, and negative values otherwise. As we move from the lowest to the highest value on the scale, we move from the candidates put in the least hopeful position by their party towards the candidates who were most certain of election by virtue of being at the right place in the right county on the right party's list.

The assumption that parties were perfectly informed about where they can expect to win more and less seats is reasonable given that each legislative election in Romania is preceded by local elections, which usually take place with four or five months before the national contest. Previous research has shown that the Romanian parties' support at constituency level is particularly stable, with correlations ranging from Pearson's $\mathrm{R}=0.74 * * *$ to Pearson's $\mathrm{R}=0.91 * * *$ across different types of elections taking place in the same year (Gherghina 2013: 151).

We expect that, in addition to these hypothesized effects, candidates' relative list placement on electoral lists are influenced, in a rather mechanic way and out of mathematical necessity, by factors that also impact the intensity of competition for top places on a given list. For purposes of both upper and lower house elections, Romania has been divided into 42 constituencies - corresponding to the 41 counties and the capital city Bucharest - which are highly unequal in terms of population size and number of seats in parliament. Parties can nominate twice as many candidates in each district than as many seats are contested there. Consequently, how many truly promising places there are on a party list, and how far behind the last electorally viable list position a candidate can be on the list, are both dependent on the regional vote share of the party and the size of the constituency. Hence our statistical analyses shall control for Party Magnitude (see above); and List Length (how many candidates the given party nominated in the given constituency). The first of these factors we will proxy with the party magnitude in the county, i.e. the number of mandates won by the party in the constituency (Schmidt 2008: 193). Both party magnitude and party list length should have a mathematically sizeable impact on how viable is the position assigned to the average candidate on each party list. In terms of substantive political meaning these effects are trivial and irrelevant, but they need to be controlled for in our models that try to estimate how much individual traits like gender or legislative 
experience make the placement of individual candidates deviate from that of the average person on the given party list.

The other independent variables in the models directly assist hypothesis testing. Hence Woman- present in all our models - is a binary variable marking women candidates. To gauge the difference between the impact of legislative and electoral experience, we estimate four models. The reason for the experimentation is to check if the findings are consistent across different operationalizations of these two, quite naturally correlated phenomena (one cannot obtain legislative experience without running in an election).

\section{Table 1 around here}

Table 1 above presents descriptive statistics: the values of the dependent, independent and control variables for the candidates included in the multivariate analyses, i.e. those from party lists that won at least one mandate (1996-2004) and for the entire population of candidates (2004). All independent variables were standardized using a 01 scale.

The proportion of incumbents varies between $9 \%$ and $15 \%$ in the viable lists samples, whereas the share of candidates who ran in the previous election increased from $19 \%$ in 1996 to $24 \%$ in 2000 and to $32 \%$ in 2004 . There is also an increase in the share of women on these viable lists: from $10 \%$ in 1996 to $14 \%$ in 2000 and to $21 \%$ in 2004 . Overall, the viable lists samples include 888 women candidates (14.2\%).

Because of collinearity problems, it proved difficult to estimate our models for one or more years if both indicators of recent and cumulative experience were entered simultaneously. Hence Models 3 and 4 concentrate on Cumulated Legislative and Cumulated Electoral Experience, which are proxied by the total number of years the candidate served in previous democratic parliaments and the number of times s/he was a candidate in prior democratic elections (minus 1990, for which we have no full data), respectively.

Models 1 and 2, in turn, focus on the impact of Recent Legislative Experience - a binary variable marking incumbents, i.e. members of the outgoing parliament - and of Recent Electoral Experience (a binary variable marking candidates who also run in the previous election). The idea is that if legislative experience as such is valued by the parties independently of the electoral experience that it implies, then it should have a statistically significant positive impact on Relative List Placement while electoral experience is controlled for.

The difference between Models 1 and 2 is the same as the difference between Models 3 and 4: the first in each pair omits, whilst the second adds Last List Placement among the independent variables. This variable is essentially a lagged dependent variable, showing the relative list placement of the same candidate in the previous election. If either electoral or legislative experience is valued by the party selectorates, then the respective variables should have an impact on how their ranking of the same candidate 
changed compared to the last election. While the control for the lagged dependent variable makes our models better suited to address the question of whether the growth of some form of political experience has a causal impact on how the candidate is valued by the party, its addition eliminates most candidates from the analysis of either year's data because most candidates did not run at all in whatever was the previous election. That is why we present the results of all four models election by election in the following section.

\section{Analysis}

Hypothesis 1 invites a comparison between how big the impact of electoral versus legislative experience is. To assist the comparison, we linearly transformed all independent variables such that their maximum value is always 1 and the minimum zero. Thus, the unstandardized regression coefficients estimated with our models allow comparing how much the expected Relative List Placement changes as we move from the minimum to the maximum value of each independent variable. ${ }^{x}$

Table 2 below presents the results of the regressions ran on the 1996 sample. The four models have a good fit, explaining approximately half of the variance. Apparently, the most important predictor for a viable list position is legislative experience: both recent (incumbency) and cumulated experience as an MP are rewarded by party gatekeepers with placement on winnable positions.

Another qualification appreciated by the selectorates seems to be the electoral experience of candidates. This could be interpreted as an apprenticeship process in which candidates that prove their loyalty by running on hopeless list positions, are later on rewarded. However, the effect is smaller than that of legislative experience.

Hypothesis 3 regarding women's general discrimination is corroborated, as they have on average significantly worse access to viable list positions compared to their male colleagues. Nevertheless, women are rewarded much more for their legislative experience than men as illustrated by model 1 . Thus, legislative experience seems to trump gendered views of candidate quality, which is a particularly important finding that goes beyond the observation that women incumbents in similar post-communist contexts had a high likelihood of securing a top list position (Kunovich 2003: 286).

\section{Table 2 around here}

Table 3 below presents the results of the regressions ran on the 2000 sample. The four models explain between 43 and $52 \%$ of the variance. Most of the findings discussed above are corroborated. Thus, legislative experience appears again the surest path towards nomination on a viable position, while electoral experience is also appreciated by electorates, although to a much smaller extent. The effects of recent and cumulated legislative experience are twice as large as the coefficients associated with recent and cumulated electoral experience. 
Once more, women candidates seem to be assigned mostly to hopeless list positions, but the effect does not reach conventional levels of statistical significance. Conversely, women incumbents and women that have a parliamentary career are consistently rewarded for this experience.

\section{Table 3 around here}

Table 4 below includes the regressions ran on the 2004 equivalent sample (i.e. excluding all party lists that failed to win a mandate).The four models explain around $42 \%$ of the variance.

As time passes, it seems that the difference between the positive effect of legislative experience and that of electoral experience in both of their recent and cumulated versions, grows larger and larger. Thus, at the 2004 elections the effect of legislative experience was 4 to 5 times higher than that of electoral experience.

In all four model specifications, compared to men, women appear to be disadvantaged in terms of nomination on viable list positions. But once again, this is reversed for the female candidates who had served in Parliament: in 2004 the magnitude of the positive effect of legislative experience for women candidates is particularly impressing.

\section{Table 4 around here}

Table 5 below presents the models ran on the whole population of candidates who participated at the 2004 elections. The model fit is similar to that of the previous regressions: the models explain between 38 and $50 \%$ of the variance. All the major findings of the regressions ran on the restricted samples presented in Tables 1-3 are corroborated: the importance of legislative experience, electoral experience, gender disadvantage as well as the privileged access to viable list positions of women with a parliamentary career. This corroboration strengthens our confidence in the robustness of the main findings of the study.

\section{Table 5 around here}

In order tobetter understand the different effects of legislative experience for male and female candidates we ran a regression on the pooled 1996-2004 data, including only those lists that won at least one mandate (the data used in tables 1-3). Then we used the STATA program Margins ${ }^{x}$ to plot the estimated effects of legislative experience for 
access to viable list positions, for male and female candidates. Figure 2 below shows the result.

One might first observe that males with no parliamentary experience are placed significantly better on average than their female colleagues who also lack such expertise. However, a change from having no legislative experience to having spent 6 years in Parliament improves only marginally, by approximately 2 list positions, the chances of an average male candidate to receive a viable list placement. After such a hypothetical increase themale candidate is still in the negative range of the dependent variable, i.e. outside the positions that offer parliamentary seats.

On the contrary, the same change in legislative experiencealmost guarantees election for afemale candidate, all other things being equal. The effect amounts to an increase of five positions on the relative list placement scale. The differentiated picture with the steeper slope, i.e. stronger impact of legislative experience for female candidates appears also if one examines separately the samples for the three elections.

\section{Figure $\mathbf{2}$ around here}

\section{Conclusion}

We started out by deriving expectations regarding the priorities of party selectorates in Romania from our observation that these parties are office- and vote-, rather than policy oriented. The derived hypotheses did not bode well for the prospects of legislative professionalization and gender equality in Romania. However, our empirical analysis suggests that the bleak expectations are only partially borne out by the data. It appears that not everything was going against prospects of legislative professionalization and gender equality in the country, at least not until the 2008 electoral system change. Legislative experience made it more likely than electoral experience that a candidate was placed on a more promising list position (Hypothesis 1 disconfirmed, Hypothesis 2 corroborated). Even then, however, parliamentary experience seems not to matter a lot in an absolute sense. Most significantly, our paper also finds that although women tend to have a hard time getting a 'safe' place on party lists (Hypothesis 3 corroborated), once they are elected, their legislative experience is rewarded a lot more than that of their male colleagues (Hypothesis 4 disconfirmed). Our model estimates suggest that among candidates of very significant legislative experience women get even better access to viable list positions than men. All this appears to signal a stronger drivetowards legislative professionalization than we may have expected.But better measures that actually tap directly into parliamentary performance, rather than just number of years in Parliament, and electoral resources, rather than just experience as number of candidacies as well as more information on other types of political experience and resources might be necessary in order to be able to evaluate more accurately the link between the nature of Romanian parties and candidate selection preferences. 
With the present data it is not possible to say if and when gender bias in legislative recruitment occurred at earlier stages than the nomination of incumbents for reelection. But women candidates were not just much fewer than men but, for whatever reason,they tended to receive lower list placement than men, which corroborates the findings of previous research on gender effects on candidate selection and also seems to confirm explanations about male party gatekeepers preferring candidates more like themselves (Niven 1998). But this disadvantage disappeared among more experienced parliamentarians. Thus, the observed under-representation of women in Romanian legislatures should probably be attributed to forces in the broader social and political context that discourage women to be involved in politics and aspire to become parliamentary candidates. Our results are consistent with the previous suggestion that closed list PR in itself - i.e. through the sheer fact of each party having more than one candidate per district and deciding the order on the list by themselves, without inferences by the voters - may not promote women's legislative representation in the absence of favorable attitudes among party selectorates and/or their translation into mandatory quotas and placement mandates (Ruedin 2012; Paxton et al 2010). On the contrary, in Eastern Europe it has been shown that citizens may be more likely to help women be elected through personal preference votes who would not have been elected given the ordered list proposed by the party were it a closed list system (Millard et al 2013).

We were not able to disentangle the effects of legislative experience from all other types of political experience though. For instance, since we do not know much about the political career outside parliament of the candidates, it might be the case that legislative experience would only matter for those who also had a record of high executive office. The effect of such combined characteristics, some of which remain unmeasured in our models, may be more prominentin the case of women MPs given their lower numbers, but we cannot judge this from our data.

Moreover, although we find that a considerable legislative experience is more likely to help women than men to better list placements, our data cannot tell anything more about how and exactly what about their legislative experience helps candidates get a better list place. We don't know whether the few women who manage to developa track record in Parliament are more likely to want to remain MPs than men with a similar profile given, for instance, professional women'smore limited alternative career options. More information aboutthe candidates' route within the party could also shed light on the mechanisms that may make legislative experience more valuable for women than for men. We do not know whether they generally have a richer experience in the party - e.g. a longer period of service in party or local government offices prior to their entry to parliament -, or if they became candidates in counties with a more decentralized and inclusive candidate selection process. It is also impossible to tell whether they were helped on their way by family or business connections with their party leadership and thus their entitlement for a safe seat at successive elections. 
This in fact reflects a more general need to understand the mechanisms of candidate nomination including variables that tap the decentralization and inclusiveness of the candidate selection processes. Moreover, further research could look more systematically into the relevance of party gender quotas as well as additional relevant candidate characteristics, such as residency in the district, local politics experience or other executive experience. Possible differences across parties may depend on their ideological leaning, their size and government/opposition status. What we could find out in this paper was nonetheless a strong hint that legislative experience is valued by Romanian parties more, relative to electoral experience, than we might have expected, and that the influence of legislative experience can even prevail over the forces that normally act to reduce the presence of women in legislatures.

\section{Notes}

The authors are grateful to Gabor Toka, Joshua Dubrow and the two anonymous reviewers for their comments and suggestions on earlier drafts. The authors acknowledgethe support received from the Romanian Ministry of National Education, CNCS-UEFISCDI, through the project PN-II-IDPCE-2012-4-0644: "Re-thinking Individual Representation: Campaign Personalization and Legislative Behaviour (2013-16)."

\section{References}

Ballington, Julie. 2005. Ten years of progress: enhancing women's political participation. In: Ten Years of Supporting Democracy Worldwide. International IDEA, Stockholm, pp. 113-124.

Baltagi, Badi. 2008. Econometric analysis of panel data (Vol. 1). John Wiley \& Sons. 
Baluta, Oana, (ed.). 2006. Gen și putere: partea leului în politica românească (Gender and power: the lion's share in Romanian politics). Iasi: Polirom.

Best, Heinrich, and Cotta, Maurizio (eds.). 2000. Parliamentary representatives in Europe, 1848-2000: legislative recruitment and careers in eleven European countries. Oxford University Press.

Chiru, Mihail. 2010. 'Turnover and Legislative Institutionalization in Romania, Hungary and Estonia', paper prepared for the conference 'Twenty Years After: Parliamentary Democracy and Parliamentary Representation in Post-Communist Europe', Jena, 7-8 May.

Chiru, Mihail. 2011. 'Invingatori dinainte: selectia candidatilor pentru colegiile necompetitive la alegerile parlamentare din 2008' (Elected before the opening of the polls: the candidate selection for the non-competitive SMDs at the 2008 legislative elections) in Gherghina, S. (ed.), Voturi şi politici. Dinamica partidelor româneşti în ultimele două decenii, (Votes and policies. The Romanian party politics dynamics in the last two decades), Iasi: Editura Institutul European.

Chiru, Mihail, Gherghina, Sergiu, and Stefan, Laurentiu. 2013. 'Standing for ReelectionUnderDifferentRules: Evidencefromthe Romanian Legislature', Problems of Post-Communism, 60(5): 34-44.

Chiru, Mihail and Gherghina, Sergiu. 2014. Let's Not Risk Too Much: The Selection of Party Leaders in Romania' in Pilet, J.-B. and Cross, W., (eds.), The Selection of Political Party Leaders in Contemporary Parliamentary Democracies: A Comparative Study, New York: Routledge.

Chiru, Mihail and Popescu, Marina. 2014. 'The Romanian Parliamentary Candidates Study 1990-2012', machine readable data file.

Chiva, Cristina. 2005. Women in Post-Communist politics: Explaining underrepresentation in the Hungarian and Romanian Parliaments. Europe-Asia Studies, 577): 969-994.

Coman, Emanuel. E. 2012. 'Legislative behavior in Romania: The effect of the 2008 Romanian electoral reform'. Legislative Studies Quarterly 37(2): 199-224.

Cox, Gary W., and Katz, Jonathan. 1996. 'Why Did the Incumbency Advantage in U.S. House Elections Grow?' American Journal of Political Science 40(2): 478-97.

Crowther, William. E., and Matonyte, Irmina. 2007. 'Parliamentary elites as a democratic thermometer: Estonia, Lithuania and Moldova compared', Communist and Post-Communist Studies, 40(3): 281-299.

Czudnowski, Moshe. 1975. 'Political recruitment' in: Greenstein, Fred I. and Polsby, Nelson (eds.)Handbook of political science: Vol. 2, Micropolitical theory. Reading, MA:Addison-Wesley.

Dubrow, Joshua K. 2006. 'Women's Representation in the Romanian Chamber of Deputies, 1992-2005: The Effect of District Economic Development'. International Journal of Sociology, 36(1): 93-109.

Dubrow, Joshua K. 2011. 'The importance of party ideology: Explaining parliamentarian support for political party gender quotas in Eastern Europe', Party Politics, 17(5): 561-579. 
Epstein, Leon D. 1980. Political parties in western democracies. New Brunswick, NJ: Praeger.

Frye, Timothy. 2002. 'The perils of polarization - economic performance in the postcommunist world', World Politics 54 (3): 308-337.

Gallagher, Tom. 2009. Romania and the European Union: how the weak vanquished the strong. Manchester: Manchester University Press.

Gelman, Andrew, and Huang, Zaiying. 2008. 'Estimating Incumbency Advantage and Its Variation, as an Example of a Before-After Study.' Journal of the American Statistical Association 103(482): 437-46

Gherghina, Sergiu. 2012. Explaining electoral volatility in Central and Eastern Europe: a party organizational approach. PhD Dissertation, Department Political Science, Faculty of Social and Behavioural Sciences, Leiden University.

Gherghina, Sergiu. 2013. 'Going for a Safe Vote: Electoral Bribes in Post-Communist Romania'. Debatte: Journal of Contemporary Central and Eastern Europe, 21(23): $143-164$.

Gherghina, Sergiu. 2014. Party Organization and Electoral Volatility in Central and Eastern Europe: Enhancing Voter Loyalty. London and New York: Routledge.

Gherghina, Sergiu and Chiru, Mihail. 2010. 'Practice and payment: Determinants of candidate list position in European Parliament elections'. European Union Politics, 11(4), 533-552.

Gherghina, Sergiu and Chiru, Mihail. 2014. 'Determinants of Legislative Voting Loyalty under Different Electoral Systems: Evidence from Romania', International Political Science Review, 35(5): 523-541.

Greene, William H. 2008. Econometric analysis, 6th ed., Upper Saddle River, N.J.: Prentice Hall

Jones, Mark P., Navia, Patricia. 1999. Assessing the effectiveness of gender quotas in open-list proportional representation electoral systems. Social Science Quarterly 80, 341-355

King, Ronald F. and Marian, Cosmin G. 2015. 'Representation, Incumbency, and the Quality of Romanian Democracy' in Lavinia Stan and Vancea, Diane (eds.) PostCommunist Romania at Twenty-Five: Linking Past, Present, and Future, 149-170.

Kelbel, Camille. 2014. National parties as gatekeepers in candidate selection for European elections. Paper presented at the Eleventh Workshop of Parliamentary Scholars and Parliamentarians, Wroxton College, Oxfordshire, July 26-27.

Kovář, Jan and Kovář, Kamil. 2013. Candidate quality across different orders of elections: the cases of the Czech Republic and Slovakia. East European Politics, 29(2): 152-174.

Kunovich, Sheri. 2003. The representation of Polish and Czech women in national politics: Predicting electoral list position. Comparative Politics, 35(3): 273-291.

Kunovich, Sheri and Paxton, Pamela. 2005. 'Pathways to Power: The Role of Political Parties in Women's National Political Representation'. American Journal of Sociology, 111(2): 505-552.

Lundell, Krister. 2004. Determinants of candidate selection. the degree of centralization in comparative perspective. Party Politics 10(1): 25-44. 
Manow, Phillip. 2007. Electoral rules and legislative turnover: Evidence from Germany's mixed electoral system. West European Politics, 30(1): 195-207.

Mansbridge, Jane. 2003. 'Rethinking representation', American political science review, 97(4): 515-528.

Matland, Richard E. 1998. Enhancing women's political participation: legislative recruitment and electoral systems. In: Karam, A. (Ed.), Women in Parliament: Beyond Numbers. International IDEA, Stockholm, pp.65-88.

Matland, Richard E. 2003. 'Women's Representation in Post-Communist Europe', in Matland, Richard E. and Montgomery, Kathleen A. (eds.), Women's Access to Political Power in Post-Communist Europe, Oxford: Oxford University Press, pp. 321-342.

Matland, Richard E., and Studlar, Donley T. 2004. Determinants of legislative turnover: a cross-national analysis. British Journal of Political Science, 34(01): 87-108.

Matthews, D.R. 1985. Legislative recruitment and legislative careers. In: Loewenberg, Gerhard, Patterson Samuel C. and Jewell Malcom E. (eds.) Handbook of legislative research. Cambridge, MA: Harvard University Press.

Mihai, Tudorina. 2011. 'Cotele de gen în politică și aplicarea lor în România' (Gender quotas in politics and their implementation in Romania), MA dissertation, SNSPA, Political Science Department, Bucharest, 71 pp.

Millard, Frances, Popescu, Marin and Toka, Gabor. 2013. 'The Impact of Preference Voting Systems on Women's Representation and the Legitimation of Quota-based Nomination Results', paper presented at the 2013 Joint Sessions of Workshops of the European Consortium for Political Research, Mainz, Germany, 11-16 March.

Miroiu, Mihaela, and Popescu, Liliana. 2004. 'Post-Totalitarian Pre-Feminism', in Carey, H. F.(ed.), Romania Since 1989-Politics, Economics, and Society, Lanham, Md.: Lexington Books, pp. 297-314.

Moraski, Bryon. 2015. 'Closed-list proportional representation in Russia: The fates of former district deputies'. Party Politics, 21(3): 381-392.

Navarro, Julien. 2012. 'Does Hard Work Pay Off? Incumbency, Parliamentary Performance and the Selection of Candidates for European Parliament Elections.' Paper presented at the Inaugural General Conference of the ECPR Standing Group on Parliaments Parliaments in Changing Time, Dublin (June 24-27)

Niven, David. 1998. Party elites and women candidates: The shape of bias. Women \& Politics, 19(2): 57-80.

Oprica, Vlad. 2008. 'Gender equality and conflicting attitudes toward women in postcommunist Romania', Human rights review, 9(1): 29-40.

Paxton, Pamela, Hughes, Melanie, and Painter, Matthew. 2010. 'Growth in Women's Political Representation: A Longitudinal Exploration of Democracy, Electoral System, and Gender Quotas', European Journal of Political Research 49 (1): 2552

Putnam, Robert, 1976. The Comparative Study of Political Elites. Prentice Hall Inc., Englewood Cliffs, NJ.

Ruedin, Didier. 2012. 'The Representation of Women in National Parliaments: A Crossnational Comparison.' European Sociological Review 28 (1): 96-109. 
Sanbonmatsu, Kira. 2002. 'Political Parties and the Recruitment of Women to State Legislatures', Journal of Politics, 64(3): 791-809.

Schmidt, Gregory D. 2009. 'The election of women in list PR systems: Testing the conventional wisdom'. Electoral Studies, 28(2), 190-203.

Semenova, Elena, Edinger, Michael and Best, Heinrich (eds.). 2013. Parliamentary Elites in Central and Eastern Europe: Recruitment and Representation(Vol. 3). Routledge, New York.

Stefan, Laurentiu. 2004. Patterns of Political Elite Recruitment in Post-Communist Romania. Bucharest: Ziua Publishing House.

Stefan, Laurentiu and Grecu, Razvan. 2013. 'The "Waiting Room": Romanian Parliament after 1989' in Semenova, Elena, Edinger, Michael and Best, Heinrich (eds.) Parliamentary Elites in Central and Eastern Europe: Recruitment and Representation, New York: Routledge, pp. 194-216.

Tavits, Margit. 2008. On the linkage between electoral volatility and party system instability in Central and Eastern Europe. European Journal of Political Research, 47(5), 537-555.

Valdini, Melody Ellis. 2012. 'A deterrent to diversity: The conditional effect of electoral rules on the nomination of women candidates', Electoral Studies, 31(4): 740-749.

'The Quota Project', data base available at: http://www.quotaproject.org/systemParty.cfm?region=50, accessed September 5, 2015. 
Table 1: Descriptive statistics of dependent variable and covariates

\begin{tabular}{|c|c|c|c|c|c|c|c|c|c|c|c|c|c|c|c|c|}
\hline \multirow{3}{*}{$\begin{array}{l}\text { Variable } \\
\text { Relative List Place }\end{array}$} & \multicolumn{2}{|c|}{$\begin{array}{c}1996 \\
N=2337\end{array}$} & & & \multicolumn{4}{|c|}{$\begin{array}{c}2000 \\
N=2124\end{array}$} & \multicolumn{4}{|c|}{$\begin{array}{c}2004 \\
N=1782\end{array}$} & \multicolumn{4}{|c|}{$\begin{array}{c}2004 \text { all lists } \\
N=10291\end{array}$} \\
\hline & Mean & S.D. & \multicolumn{2}{|c|}{ Min/Max } & Mean & S.D. & \multicolumn{2}{|c|}{ Min/Max } & Mean & S.D. & \multicolumn{2}{|c|}{ Min/Max } & Mean & S.D. & \multicolumn{2}{|c|}{ Min/Max } \\
\hline & -4.17 & 5.39 & -36 & 16 & -3.93 & 4.96 & -33 & 13 & -3.63 & 4.42 & -32 & 8 & -4.89 & 4.81 & -35 & 8 \\
\hline List Length & 0.28 & 0.23 & 0 & 1 & 0.27 & 0.22 & 0 & 1 & 0.21 & 0.22 & 0 & 1 & 0.24 & 0.21 & 0 & 1 \\
\hline lagnitude & 0.07 & 0.14 & 0 & 1 & 0.10 & 0.17 & 0 & 1 & 0.14 & 0.21 & 0 & 1 & 0.04 & 0.12 & 0 & 1 \\
\hline Rece & 0.19 & 0.39 & 0 & 1 & 0.24 & 0.42 & 0 & 1 & .32 & 0.47 & 0 & 1 & 0.08 & 0.26 & 0 & 1 \\
\hline Rece & 0.11 & 0.31 & 0 & 1 & 0.09 & 0.29 & 0 & 1 & 0.15 & 0.36 & 0 & 1 & 0.03 & 0.17 & 0 & 1 \\
\hline Cum & 0.19 & 0.39 & 0 & 1 & 0.16 & 0.29 & 0 & 1 & 0.17 & 0. & 0 & 1 & .05 & 0.15 & 0 & 1 \\
\hline Cum & 0.09 & 0.25 & 0 & 1 & 0.06 & 0.19 & 0 & 1 & 0.07 & 0.18 & 0 & 1 & 0.01 & 0.08 & 0 & 1 \\
\hline Wom & 0.10 & 0.30 & 0 & 1 & 0.14 & 0.34 & 0 & 1 & 0.21 & 0.4 & 0 & 1 & 0.28 & 0.45 & 0 & 1 \\
\hline Woma & 0.00 & 0.06 & 0 & 1 & 0.01 & 0.08 & 0 & 1 & 0.02 & 0.14 & 0 & 1 & 0.00 & 0.06 & 0 & 1 \\
\hline Woman Cum & 0.00 & 0.05 & 0 & 1 & 0.00 & 0.05 & 0 & 1 & 0.01 & 0.07 & 0 & 1 & 0.00 & 0.03 & 0 & 1 \\
\hline Last List Place & 0.13 & 0.26 & 0 & 1 & 0.15 & 0.28 & 0 & 1 & 0.16 & 0.25 & 0 & 1 & 0.04 & 0.14 & 0 & 1 \\
\hline
\end{tabular}


Table 2: Determinants of viable list placement at the 1996 elections (OLS models)

\begin{tabular}{|c|c|c|c|c|}
\hline & Model 1 & Model 2 & Model 3 & Model 4 \\
\hline Recent Electoral Experience & $\begin{array}{l}1.094 * * * \\
(0.291)\end{array}$ & & & \\
\hline Recent Legislative experience & $\begin{array}{l}3.036 * * * \\
(0.373)\end{array}$ & $\begin{array}{l}1.060 * * * \\
(0.380)\end{array}$ & & \\
\hline Woman & $\begin{array}{l}-0.992^{* * *} \\
(0.276)\end{array}$ & $\begin{array}{l}1.237 \\
(0.847)\end{array}$ & $\begin{array}{l}-0.973 * * * \\
(0.276)\end{array}$ & $\begin{array}{l}1.732^{* *} \\
(0.876)\end{array}$ \\
\hline Woman * Recent Leg. Exp. & $\begin{array}{l}3.217^{* *} \\
(1.422)\end{array}$ & $\begin{array}{l}-0.695 \\
(1.389)\end{array}$ & & \\
\hline Last List Placement & & $\begin{array}{l}19.818^{* * *} \\
(2.021)\end{array}$ & & $\begin{array}{l}20.212^{* * *} \\
(2.033)\end{array}$ \\
\hline Cumulated Electoral Experience $^{1}$ & & & $\begin{array}{l}1.065^{* * *} \\
(0.293)\end{array}$ & \\
\hline Cumulated Legislative Experience & & & $\begin{array}{l}3.820 * * * \\
(0.462)\end{array}$ & $\begin{array}{l}1.298^{* * *} \\
(0.471)\end{array}$ \\
\hline Woman * Cumulated Leg. Exp. & & & $\begin{array}{l}2.557 \\
(1.650)\end{array}$ & $\begin{array}{l}-2.352 \\
(1.660)\end{array}$ \\
\hline List Length & $\begin{array}{l}-17.017 * * * \\
(0.407)\end{array}$ & $\begin{array}{l}-8.641 * * * \\
(0.774)\end{array}$ & $\begin{array}{l}-17.016^{* * *} \\
(0.407)\end{array}$ & $\begin{array}{l}-8.624 * * * \\
(0.772)\end{array}$ \\
\hline Party Magnitude & $\begin{array}{l}15.206^{* * * *} \\
(0.671)\end{array}$ & $\begin{array}{l}13.886^{* * * *} \\
(1.178)\end{array}$ & $\begin{array}{l}15.208^{* * * *} \\
(0.671)\end{array}$ & $\begin{array}{l}13.796 * * * \\
(1.777)\end{array}$ \\
\hline Constant & $\begin{array}{l}-1.026^{* * *} \\
(0.133)\end{array}$ & $\begin{array}{l}-14.069 * * * \\
(1.242)\end{array}$ & $\begin{array}{l}-1.028^{* * *} \\
(0.133)\end{array}$ & $\begin{array}{l}-14.324 * * * \\
(1.247)\end{array}$ \\
\hline $\mathrm{N}$ & 2337 & 445 & 2337 & 445 \\
\hline $\mathrm{R}^{2}$ & .481 & .504 & .480 & .505 \\
\hline
\end{tabular}

$*$ Significance at $* p<0.10, * * p<0.05, * * * p<0.01$

\footnotetext{
${ }^{1}$ This variable is omitted from model 4 because it is constant: all the candidates remaining in the sample had run in the previous election, in 1992.
} 
Table 3: Determinants of viable list placement at the 2000 elections (OLS models)

\begin{tabular}{|c|c|c|c|c|}
\hline & Model 1 & Model 2 & Model 3 & Model 4 \\
\hline Recent Electoral Experience & $\begin{array}{l}1.407 * * * \\
(0.229)\end{array}$ & & & \\
\hline Recent Legislative experience & $\begin{array}{l}3.685^{* * *} \\
(0.349)\end{array}$ & $\begin{array}{l}1.137 * * * \\
(0.279)\end{array}$ & & \\
\hline Woman & $\begin{array}{l}-0.261 \\
(0.245)\end{array}$ & $\begin{array}{l}-0.342 \\
(0.443)\end{array}$ & $\begin{array}{l}-0.289 \\
(0.248)\end{array}$ & $\begin{array}{l}-0.367 \\
(0.443)\end{array}$ \\
\hline Woman $*$ Recent Leg. Exp. & $\begin{array}{l}2.031^{*} \\
(1.097)\end{array}$ & $\begin{array}{l}0.955^{* *} \\
(0.799)\end{array}$ & & \\
\hline Last List Placement & & $\begin{array}{l}19.809 * * * \\
(1.735)\end{array}$ & & $\begin{array}{l}20.857 * * * \\
(1.694)\end{array}$ \\
\hline Cumulated Electoral Experience & & & $\begin{array}{l}2.117 * * * \\
(0.381)\end{array}$ & $\begin{array}{l}-1.363^{* *} \\
(0.630)\end{array}$ \\
\hline Cumulated Legislative Experience & & & $\begin{array}{l}4.450 * * * \\
(0.605)\end{array}$ & $\begin{array}{l}1.799 * * * \\
(0.507)\end{array}$ \\
\hline Woman * Cumulated Leg. Exp. & & & $\begin{array}{l}4.215^{* * *} \\
(1.606)\end{array}$ & $\begin{array}{l}1.709 \\
(1.160)\end{array}$ \\
\hline List Length & $\begin{array}{l}-16.656 * * * \\
(0.492)\end{array}$ & $\begin{array}{l}-4.180 * * * \\
(0.791)\end{array}$ & $\begin{array}{l}-16.680^{* * *} \\
(0.497)\end{array}$ & $\begin{array}{l}-3.852 * * * \\
(0.794)\end{array}$ \\
\hline Party Magnitude & $\begin{array}{l}11.558^{* * * *} \\
(0.645)\end{array}$ & $\begin{array}{l}9.688^{* * * *} \\
(0.881)\end{array}$ & $\begin{array}{l}11.668^{* * * *} \\
(0.653)\end{array}$ & $\begin{array}{l}9.614 * * * \\
(0.890)\end{array}$ \\
\hline Constant & $\begin{array}{l}-1.185^{* * *} \\
(0.144)\end{array}$ & $\begin{array}{l}-14.379 * * * \\
(1.097)\end{array}$ & $\begin{array}{l}-1.137 * * * \\
(0.145)\end{array}$ & $\begin{array}{l}-14.272^{* * *} \\
(1.173)\end{array}$ \\
\hline $\mathrm{N}$ & 2124 & 500 & 2124 & 500 \\
\hline $\mathrm{R}^{2}$ & .439 & .520 & .426 & .515 \\
\hline
\end{tabular}

* Significance at $* p<0.10, * * p<0.05, * * * p<0.01$ 
Table 4: Determinants of viable list placement at the 2004 elections (OLS models)

\begin{tabular}{|c|c|c|c|c|}
\hline & Model 1 & Model 2 & Model 3 & Model 4 \\
\hline Recent Electoral Experience & $\begin{array}{l}0.518^{* *} \\
(0.223)\end{array}$ & & & \\
\hline Recent Legislative experience & $\begin{array}{l}2.679 * * * \\
(0.300)\end{array}$ & $\begin{array}{l}0.573 * \\
(0.340)\end{array}$ & & \\
\hline Woman & $\begin{array}{l}-1.241 * * * \\
(0.212)\end{array}$ & $\begin{array}{l}-1.115^{* *} \\
(0.551)\end{array}$ & $\begin{array}{l}-1.272 * * * \\
(0.210)\end{array}$ & $\begin{array}{l}-0.892 * \\
(0.512)\end{array}$ \\
\hline Woman * Recent Leg. Exp. & $\begin{array}{l}2.481 * * * \\
(0.664)\end{array}$ & $\begin{array}{l}1.558^{* *} \\
(0.777)\end{array}$ & & \\
\hline Last List Placement & & $\begin{array}{l}15.881 \text { *** } \\
(1.433)\end{array}$ & & $\begin{array}{l}15.788 * * * \\
(1.362)\end{array}$ \\
\hline Cumulated Electoral Experience & & & $\begin{array}{l}1.124 * * \\
(0.449)\end{array}$ & $\begin{array}{l}-1.051 \\
(0.747)\end{array}$ \\
\hline Cumulated Legislative Experience & & & $\begin{array}{l}4.851^{* * *} \\
(0.685)\end{array}$ & $\begin{array}{l}1.920 * * \\
(0.775)\end{array}$ \\
\hline Woman * Cumulated Leg. Exp. & & & $\begin{array}{l}6.674 * * * \\
(1.309)\end{array}$ & $\begin{array}{l}2.661^{*} \\
(1.462)\end{array}$ \\
\hline List Length & $\begin{array}{l}-15.045^{* * *} \\
(0.534)\end{array}$ & $\begin{array}{l}-6.926 * * * \\
(0.801)\end{array}$ & $\begin{array}{l}-15.255^{* * *} \\
(0.533)\end{array}$ & $\begin{array}{l}-6.848^{* * *} \\
(0.807)\end{array}$ \\
\hline Party Magnitude & $\begin{array}{l}7.003 * * * \\
(0.560)\end{array}$ & $\begin{array}{l}2.041 * * \\
(0.871)\end{array}$ & $\begin{array}{l}7.102^{* * * *} \\
(0.559)\end{array}$ & $\begin{array}{l}1.868 * * \\
(0.883)\end{array}$ \\
\hline Constant & $\begin{array}{l}-1.792 * * * \\
(0.134)\end{array}$ & $\begin{array}{l}-9.390 * * * \\
(0.671)\end{array}$ & $\begin{array}{l}-1.730^{* * *} \\
(0.132)\end{array}$ & $\begin{array}{l}-8.948 * * * \\
(0.733)\end{array}$ \\
\hline $\mathrm{N}$ & 1782 & 562 & 1782 & 562 \\
\hline $\mathrm{R}^{2}$ & .414 & .422 & .418 & .423 \\
\hline
\end{tabular}

* Significance at * p $<0.10, * * p<0.05, * * * p<0.01$ 
Table 5: Determinants of viable list placement for all the candidates at the 2004 elections (OLS models)

\begin{tabular}{|c|c|c|c|c|}
\hline & Model 1 & Model 2 & Model 3 & Model 4 \\
\hline Recent Electoral Experience & $\begin{array}{l}0.480 * * * \\
(0.165)\end{array}$ & & & \\
\hline Recent Legislative experience & $\begin{array}{l}2.591 * * * \\
(0.265)\end{array}$ & $\begin{array}{l}0.825^{* * *} \\
(0.269)\end{array}$ & & \\
\hline Woman & $\begin{array}{l}-0.652 * * * \\
(0.077)\end{array}$ & $\begin{array}{l}-0.667^{*} \\
(0.396)\end{array}$ & $\begin{array}{l}-0.626 * * * \\
(0.077)\end{array}$ & $\begin{array}{l}-0.609 \\
(0.380)\end{array}$ \\
\hline Woman $*$ Recent Leg. Exp. & $\begin{array}{l}1.785 * * * \\
(0.613)\end{array}$ & $\begin{array}{l}1.074 * \\
(0.625)\end{array}$ & & \\
\hline Last List Placement & & $\begin{array}{l}13.454 * * * \\
(1.125)\end{array}$ & & $\begin{array}{l}13.304 * * * \\
(1.096)\end{array}$ \\
\hline Cumulated Electoral Experience & & & $\begin{array}{l}1.653 * * * \\
(0.306)\end{array}$ & $\begin{array}{l}-0.912 \\
(0.575)\end{array}$ \\
\hline Cumulated Legislative Experience & & & $\begin{array}{l}4.357 * * * \\
(0.572)\end{array}$ & $\begin{array}{l}2.359 \\
(0.611)\end{array}$ \\
\hline Woman $*$ Cumulated Leg. Exp. & & & $\begin{array}{l}5.211^{* * *} \\
(1.234)\end{array}$ & $\begin{array}{l}2.194 * \\
(1.230)\end{array}$ \\
\hline List Length & $\begin{array}{l}-15.838^{* * *} \\
(0.164)\end{array}$ & $\begin{array}{l}-7.231 * * * \\
(0.727)\end{array}$ & $\begin{array}{l}-15.846 * * * \\
(0.164)\end{array}$ & $\begin{array}{l}-7.220 * * * \\
(0.729)\end{array}$ \\
\hline Party Magnitude & $\begin{array}{l}6.614 * * * \\
(0.312)\end{array}$ & $\begin{array}{l}2.405^{* * *} * \\
(0.760)\end{array}$ & $\begin{array}{l}6.504 * * * \\
(0.308)\end{array}$ & $\begin{array}{l}2.270 * * * \\
(0.765)\end{array}$ \\
\hline Constant & $\begin{array}{l}-1.357^{* * *} \\
(0.056)\end{array}$ & $\begin{array}{l}-8.150 * * * \\
(0.536)\end{array}$ & $\begin{array}{l}-1.386 * * * \\
(0.056)\end{array}$ & $\begin{array}{l}-7.698 * * * \\
(0.585)\end{array}$ \\
\hline $\mathrm{N}$ & 10921 & 773 & 10921 & 773 \\
\hline $\mathrm{R}^{2}$ & .494 & .382 & .497 & .385 \\
\hline
\end{tabular}




\begin{tabular}{|c|c|}
\hline Variable & Operationalization \\
\hline Relative List Placement & $\begin{array}{l}\text { The difference between the party magnitude and the } \\
\text { list rank of the candidate. }\end{array}$ \\
\hline List Length & $\begin{array}{l}0-1 \text { standardized scale based on the number of } \\
\text { candidates that composed the party list in the county. }\end{array}$ \\
\hline Party Magnitude & $\begin{array}{l}0-1 \text { standardized scale based on the number of } \\
\text { mandates won by party in county at the election. }\end{array}$ \\
\hline $\begin{array}{l}\text { Recent Electoral } \\
\text { Experience }\end{array}$ & $\begin{array}{l}1=\text { the candidate ran in the previous parliamentary } \\
\text { election. }\end{array}$ \\
\hline $\begin{array}{l}\text { Recent Legislative } \\
\text { Experience }\end{array}$ & $1=$ the candidate is an incumbent MP. \\
\hline Woman & $1=$ the MP is a woman. \\
\hline $\begin{array}{l}\text { Cumulated Electoral } \\
\text { Experience }\end{array}$ & $\begin{array}{l}0-1 \text { standardized scale based on the number of times } \\
\text { the candidate participated in parliamentary elections. }\end{array}$ \\
\hline $\begin{array}{l}\text { Cumulated Legislative } \\
\text { Experience }\end{array}$ & $\begin{array}{l}0-1 \text { standardized scale based on the number of years of } \\
\text { parliamentary experience. }\end{array}$ \\
\hline $\begin{array}{l}\text { Woman Cumulated } \\
\text { Electoral Experience }\end{array}$ & $\begin{array}{l}\text { Interaction term between being a woman and the scale } \\
\text { measuring electoral experience. }\end{array}$ \\
\hline Woman Cumulated & Interaction term between being a woman and the scale \\
\hline Legislative Experience & measuring legislative experience. \\
\hline Last List Placement & $\begin{array}{l}0-1 \text { standardized scale based on the relative list } \\
\text { placement at the previous parliamentary election. }\end{array}$ \\
\hline
\end{tabular}


Figure 1: Percentage of women and incumbents among all candidates and elected MPs in Romania, 1992-2012

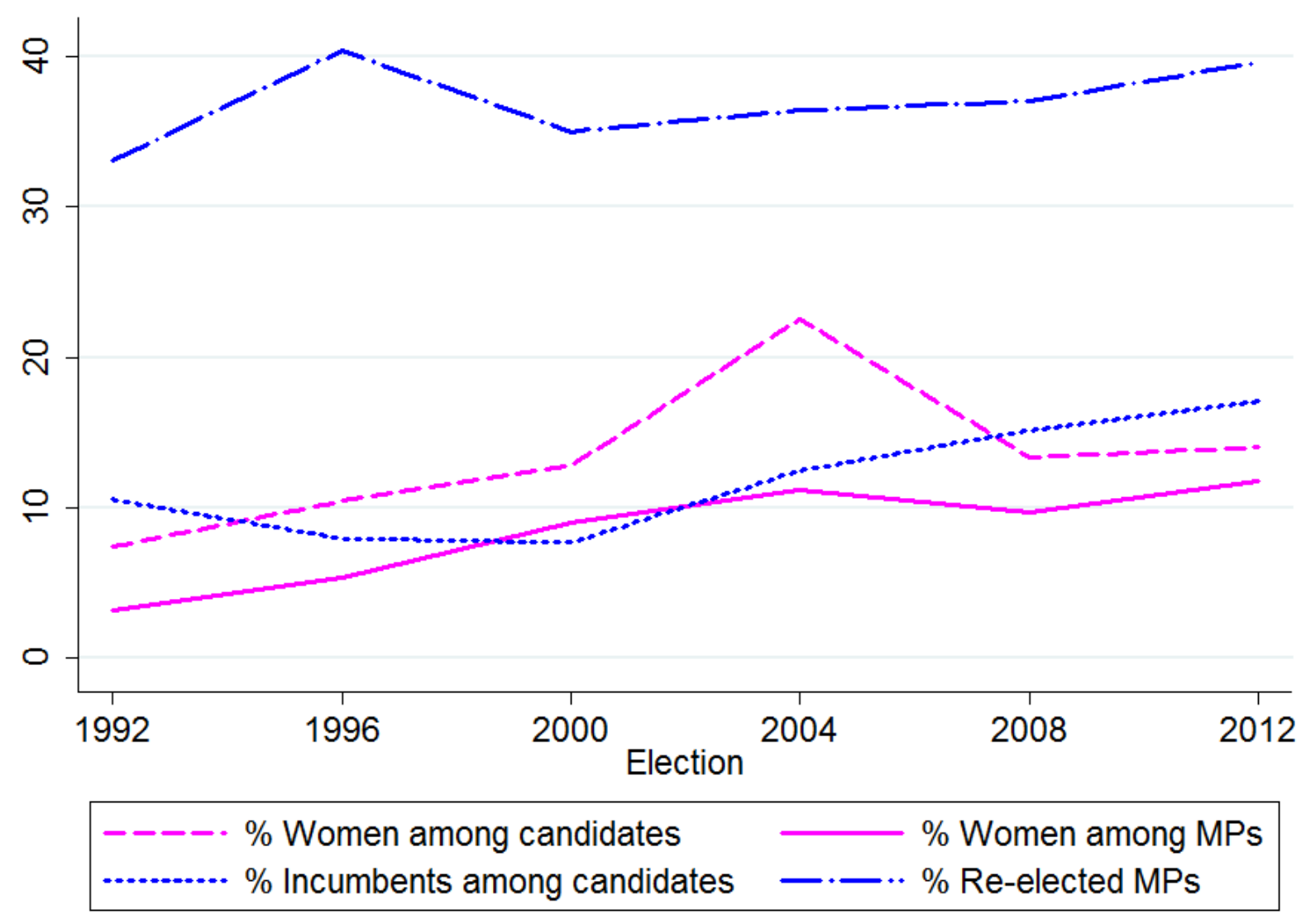


Figure 2: The effect of legislative experience for male and female candidates
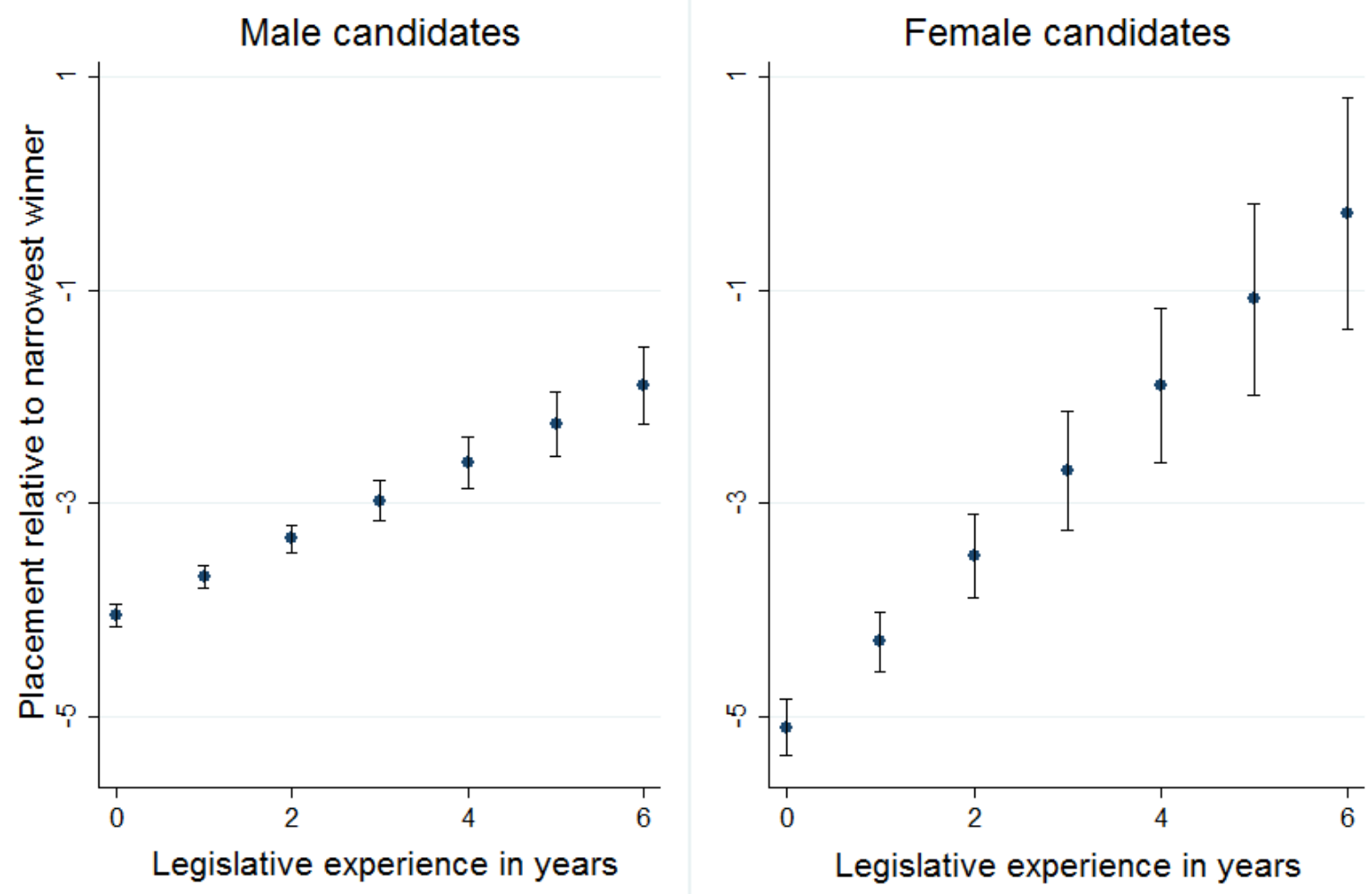

- Expected placement at mean value of other variables $\longmapsto 95 \% \mathrm{Cl}$ 
'Oxford School of Global and Area Studies, University of Oxford. Email address:

mihail.chiru@area.ox.ac.uk, phone: 07518407676; postal address: 11 Bevington Road, UK, OX2 6NB.

iCentral European University Budapest; Lucian Blaga University Sibiu.

iiiUnder closed list PR each of Romania's 42 counties was a multimember district, with district magnitude varying between 4 and 29, and a mean of around 6 for the Chamber of Deputies and between 2 and 13, with a mean of around 4 for the Senate.

iv Figure 1 illustrates the percentages of women and incumbent candidates in parties that were represented in parliament prior to - or were about to gain parliamentary representation in - particular election from 1992 until 2012. Comparing the shares of incumbent candidates and re-elected MPs it is evident that incumbents seem to have better chances of getting elected than newcomers. Generally, there seems to be a relatively good match between the supply side and the trend of women parliamentary representation.

"Fully corroborating this point would require a multivariate regression, that would control, among other things, for party affiliation as incumbents tend to belong to bigger parties that pick up more seats.

vi Scholars studying legislative professionalization consider turnover rates of $30-35 \%$ to be the optimal level of parliamentary renewal (Crowther and Matonyte 2007: 291; Best and Cotta 2000)

viiWomen candidates being disadvantaged by the party selectorates has also been documented in open list elections in other post-communist countries (Kunovich 2003: 279, Millard et al 2013).

viiiThe latter aspect resulted mostly in having fewer UDMR candidates in the samples because the support basis of this ethnic party is regionally very concentrated. Several Freedom of Information requests were made to obtain the complete lists of candidates for the first four parliamentary elections (1990-2000) from the Permanent Electoral Authority, the National State Archives and the 42 county tribunals. Virtually all of these attempts failed as most tribunals responded that they destroyed the candidate lists considering them voting materials (such as voting ballots), which under the law have to be destroyed three months after the elections.

${ }^{\text {ix }}$ After matching the 1992-2004 data we observed that $89 \%$ of the candidates in the sample ran only in one election, $8.2 \%$ participated in 2 elections, $2.2 \%$ ran in 3 whereas only $0.4 \%$ appeared in all 4 elections. Overall, we have in the sample 1,799 candidates who ran in two or more elections. The share of candidates that participated in more than one election was the highest in the UDMR sample (47\%), followed by PSD (40\%), PD and PRM (36\%) and PNL (31\%). These levels of re-nomination point to a relatively high volatility of party cadres, which in is line with previous empirical research that focused on the re-nomination rates of MPs only (Gherghina 2014).

${ }^{x}$ To adjust the estimated impact for the unequal variance of the different independent variables we also estimated standardized regression coefficients, which are available on request.

xiThe program calculates the value of the dependent variable from predictions of a previously fit model at fixed values of the key independent variable(s) while keeping at their average the remaining covariates. 